\title{
The Correlation between Parenting Styles and School Readiness for Children with Hearing Impairment
}

\author{
Dyah Retno Septiani, Munawir Yusuf \\ Universitas Sebelas Maret, Indonesia \\ Email: dyahretno2@gmail.com
}

\begin{abstract}
The readiness of students to start learning is the first important thing in the learning process. Readiness is the overall condition of a person in adjusting with the conditions. It is assumed that readiness is influenced by parenting styles. This research aims to determine the correlation between parenting styles and school readiness for children with hearing impairment. This research used quantitative approach with correlational design. The data were collected using a questionnaire and analyzed using linear regression. The results of this research showed that both simultaneously and partially there is no significant correlation between parenting styles and school readiness for children with hearing impairment.
\end{abstract}

Keywords: children with hearing impairment, school readiness, parenting styles

\section{INTRODUCTION}

The readiness of students to start learning is the first thing that is very important in the learning process. Readiness is the overall condition of a person who makes it ready to give a response / answer in a certain way to a situation and related to the adjustment of conditions (Slameto, 2010). The condition of students influences the readiness of learning not only physically, but also psychologically and materially (Djamarah, 2002). Learning readiness or school readiness can generally be seen when students attend elementary schools. According to Slameto (2010) readiness is a prerequisite for subsequent learning. Therefore, readiness which is a capacity that exists in students will be related to certain teaching goals (Hamalik, 2003).

Aspects that are included in school readiness are physical health, gross and fine motor skills, approaches to learning, social - emotional development, and language / communication development (Pyle, 2009). Where as Slameto (2010) revealed the school's readinesseconsists of two aspects which are maturity and intelligence.aA previous study in California which examined 112 students in pre-school in the summer learning program found that the highest score was on the social-emotional aspect, then the learning approach scoreeincluding the child's behavior, and finally the language development (Pyle, 2009).

The aspects of school readiness are influenced by several factore which include physical conditions that are not conducive and psychological conditions that are not good (Darsono, 2000). On the other hand Djamarah (2002) revealed that the factors that influence school readiness are physical readiness, psychological readiness, and material readiness such as materials to be studied or worked on (reading books, exercise books, notes, etc.). Previous research also mentions that school readiness, psychological conditions, and children's social relations are significantly influenced by children's social-emotional competencies (Duncan et al., 2007).

Child competency in social - emotional can be interpreted as "how much capacity of children to interact with their environment (parents, teachers, and peers)". Children's interaction with the environment starts from the interaction of children with parents. Parents have an important role and a big influence on children's lives (Bibi et al., 2013). One thing that reflects the relationship between parents and children is called parenting styles, which is a complex activity consisting of specific ways of thinking and behavior that can work separately or together so that it can influence the results of education and emotional bonding in children (Bibi et al., 2013). According to Baumrind (1971) parenting styles consists of three aspecte which are authoritative parenting, authoritarian parenting, and permissive parenting.

The third aspect of parenting have different characteristice such as 1) Authoritative parenting, characterized by a warm relationship,facceptance of the children's points of view, and encouragemene for children's participation in making a decision (Berg, 2011); 2) Authoritarian parenting, characterized by implementation of high standards andethe urge to give guidance and to require a child to be always obedient so that a loving relationship of parents with children is based on the 
level of success ofdtheir children (Berg, 2011), and 3) Permissive parenting, characterized byygiving freedom and not controlling children's behavior unlessdthey havs physical injuries (Rossman \& Rea, 2005). Parenting aspects are influenced by two main factore including the ability to reacn and the demands of parents (Fletcher et al., 2008).

Based on the description above, the researcher wants to reveal "The Correlation between Parenting Styles and School Readiness for Children with Hearing Impairment". The problem statement from this study is "Is there any correlation between parenting styles and school readinessfin Children with hearing impairment?". This study aims to find out the correlation between parenting styles and school readiness forf children with hearing impairment.

\section{METHOD}

The researchsapplied quantitative correlational approach. The subjects chosen in this study were hearing impaired students in the $1^{\text {st }}$ and $2^{\text {nd }}$ grade of elementary school comprising of 33 children. ThisRresearch was carried out in two schools providing education for children with hearing impairment in Surakartay. Ths research was conductedffrom September to October 2018.

There are two variables thateare examined in this stude which are parenting styles and school readiness of children with hearing impairment. Dataewere collected using a research scale, named Likert scale. The scaleywas used to measure parenting styles as referred in the concept of Baumrind (1971) which states that the dimensions of the parenting styles variables consist of 1) authoritative parentin ,2)nauthoritarian parenting, and 3) permissive parenting. Medium scale to measure school readiness are modified from the scale compiled by the Center for School - Based Youth Development of California that contains the variable dimensions or aspects of school readiness among social - emotional, language development, and approaches to learning.

The data analysis used in this research is double linear regression processed by SPSS 21.

\section{FINDINGS AND DISCUSSION}

\section{Findings}

Based on the number of samplesowhich are 33 students with hearing impairment in the $1^{\text {st }}$ and $2^{\text {nd }}$ grade, the parents are the respondents to show the $\mathrm{X}$ variable. The independent variable (parenting style) in this study was categorized in 3 parenting styles (X) which are authoritative parenting (X1), authoritarian parenting (X2), and permissive parenting (X3). The three parenting styles are related to the dependent variable (e that includes school readiness of children with hearing impairment who are described by a scale that has been filled by the class teacher. Before knowing the correlation between the $\mathrm{X}$ and $\mathrm{Y}$ variables, researchers mustsconduct a preliminary test first.

The preliminary test that was done is 1) Test for normality, aiming to see whether a range of data can be said the data distribution as a normal variable. Calculation of the normality test using the SPSS version 21 program with the One-Sample Kolmogorov-Smirnov Test technique shows that the distribution of data is normal. This is also indicated by the Normal QQ plot of Y where the distribution of data is around the diagonal line, 2) Homogeneity / heterocycedasticity test using a scatterplot test. The results of this test are plot graphs that do not form a specific pattern so that data can be said to be homogeneous or have similar variants. 3) Linearity test, the rule used to determine the data linearity is if the significance $>0.05$, there is a significant linear correlation between $\mathrm{X}$ variables with $\mathrm{Y}$ variables. The test results show the value of $F$ on variables of $\mathrm{X}$ with $\mathrm{Y}$ is 0.546 with a significance of $0.883 ; \mathrm{F}$ on variable of $\mathrm{X} 1$ with $\mathrm{Y}$ is 1.714 with a significance of 0.139 ; $\mathrm{F}$ on variable of $\mathrm{X} 2$ with $\mathrm{Y}$ is 0.857 with a significance of 0.599 ; and $\mathrm{F}$ on variable of $\mathrm{X} 3$ with $\mathrm{Y}$ is 0.365 with a significance of 0.969 . The three results of linearity testing on independent variables with dependent variables indicate that the correlation between independent variables (parenting styles) and the dependent variable (school readiness) is significantly linear.

Through linear regression analysis a constant value of 40.417 means that if the $\mathrm{Y}$ variable (school readiness) is not related to the three $\mathrm{X}$ variables or $\mathrm{X} 1, \mathrm{X} 2$, and $\mathrm{X} 3$ variables worth zero, then the average of school readiness for deaf children will be 40.417. Based on the hypothesis test through the F test, the $F$ value of 0.145 obtained a significance level of 0.932 means that simultaneously the $\mathrm{X}$ variable (parenting style) does not affect the $\mathrm{Y}$ variable (school readiness). While partially through the $t$ test, it is found that the $t$ coefficient at $X 1$ is 0.158 with a significance level of 0.876 ; $t$ coefficient on $\mathrm{X} 2$ is -0.303 with a significance level of 0.764 ; and the $t$ coefficient on X3 is 0.573 with a significance level of 0.571 . Based on the results of the $t$ test it can be said that partially there is no correlation between $\mathrm{X} 1$ and $\mathrm{Y}, \mathrm{X} 2$ with $\mathrm{Y}$, and $\mathrm{X} 3$ with $\mathrm{Y}$. This is indicated by a significance level that is more than 0.05 .

The results of the correlation analysis also show the value of $R \quad 0.121$, meaning that if there is a relationship between the independent variable and the dependent variable, it is very weak. Moreover, 
the results of testing the coefficient of determination that aims to explain the goodness of the regression model in the dependent variable shows the $\mathrm{R}$ square value is 0.015 or $1,5 \%$. This means that the variables studied (parenting styles) only have an effect on school readiness as much as $1,5 \%$ while the rest are influenced by other variables that are not examined in this study.

\section{Discussion}

Based on the results of testing through SPSS version 21 above,wit is known that both the simultaneously and partially parenting styles have no effect or are not related to the school readiness of children with hearing impairment. Because of the lack of reference to previous research regarding the school readinessrof children with hearing impairment, the researcherl compared this result with the school readiness ofrnormal children. Some previous research states that there is a significant correlation between parenting styles and children's school readiness, especially with parents who have more time with childrenncompared to parents who only briefly accompany the child (Majzub \& Rashid, 2012).

But the results of this study are supported by several previous studies which stated that not all families are in accordance with the parenting styles according to Baumrind, especially parents who are outside of western countries. This is supported by research in Saudi Arabia which states that three forms of parenting ( controlling, flexible and inconsistent) that are combined with the categories compiled by Baumrind show a more specific parenting orientation (Dwairy et al., 2006). Research in Korea also shows that only $26 \%$ of Korean-American familiesefall into Baumrind's parenting category (Kim \& Rohner, 2002; Magdalena, 2014).

This shows that culture has a big role in parenting. In addition to culture, gender and individual differences also influence parenting styles (Kochanska et al., 2004; Rahimpour et al., 2014). However, many research mentioned that children need a balanced relationship with parente such asewarmth (acceptance - rejection) and control (freedom - punishment) that are applied based on the demands and personal needs of the children (Checa \& Abundis-Gutierrez, 2018). The establishment of a balanced relationship between parents and children that focuses on the personal conditions of children will affect the success of children in interacting with their environment both home and school environment, especially in early childhood (Magdalena, 2014). If the interaction goes well, it will also affect children's school or learning readiness and children's achievement in school (Majzub \& Rashid, 2012).

\section{CONCLUSION}

Based on the results of the research above, it can be concluded that both simultaneously and partially there is no significant correlation between parenting styles and school readiness for children with hearing impairment. However parents have an important role in children's development in the form of social-emotional development, language development, and developments in learning including children's behavior. The role is the same as the aspect of school readiness, so that if parents want to set aside time for children, and establish two-way communication between parents - school then the child will develop well.

\section{REFERENSI}

Baumrind, D. (1971). Current Pattern of Parental Authority. America: American Psychological Association.

Berg, B. (2011). The Effects of Parenting Styles on a Preschool Aged Child's Social Emotional Development. The Graduate School, University of Wisconsin-Stout.

Bibi, F., Chaudhry, A. G., Awan, E. A., \& Tariq, B. (2013). Contribution of parenting style in life domain of children. IOSR Journal of humanities and social science (IOSR-JHSS), 12(2), 91-95.

Checa, P., \& Abundis-Gutierrez, A. (2018). Parenting Styles, Academic Achievement and the Influence of Culture. Psychology and Psychotherapy:Research Study, 1(4), 1-3.

Darsono. (2000). Belajar dan Pembelajaran. Semarang: IKIP Semarang Publisher.

Djamarah, S. B. (2002). Strategi Belajar Mengajar. Jakarta: Rineka Cipta.

Duncan, G. J., Dowsett, C. J., Claessens, A., Magnuson, K., Huston, A. C., Klebanov, P., ... \& Sexton, H. (2007). School readiness and later achievement. Developmental psychology, 43(6), 1428-1446.

Dwairy, M., Achoui, M., Abouserie, R., Farah, A., Sakhleh, A. A., Fayad, M., \& Khan, H. K. (2006). Parenting styles in Arab societies: A first crossregional research study. Journal of Cross-Cultural Psychology, 37(3), 230-247.

Fletcher, A. C., Walls, J. K., Cook, E. C., Madison, K. J., \& Bridges, T. H. (2008). Parenting style as a moderator of associations between maternal disciplinary strategies and child well-being. Journal of Family issues, 29(12), 1724-1744.

Hamalik, O. (2003). Pendidikan Guru: Berdasarkan Pendekatan Kompetensi. Jakarta: Bumi Aksara.

Kim, K., \& Rohner, R. P. (2002). Parental warmth, control, and involvement in schooling: Predicting academic achievement among Korean American adolescents. Journal of cross-cultural psychology, 33(2), 127-140. 
Kochanska, G., Friesenborg, A. E., Lange, L. A., \& Martel, M. M. (2004). Parents' personality and infants' temperament as contributors to their emerging relationship. Journal of personality and social psychology, 86(5), 744-759.

Magdalena, S. M. (2014). The effects of parental influences and school readiness of the child. Procedia-Social and Behavioral Sciences, 127, 733-737.

Rahimpour, P., Direkvand-Moghadam, A., DirekvandMoghadam, A., \& Hashemian, A. (2015). Relationship Between the Parenting Styles and Students' Educational Performance Among Iranian Girl High School Students, A Cross-Sectional Study. Journal of Clinical and Diagnostic Research: JCDR, 9(12), JC05.
Majzub, R. M., \& Rashid, A. A. (2012). School readiness among preschool children. ProcediaSocial and Behavioral Sciences, 46, 3524-3529.

Pyle, R. P. (2009). Santa Barbara School Readiness Scale: School Readiness Needs of Latino Preschoolers. Center for School-Based Youth Development, 1-8.

Rossman, B. R., \& Rea, J. G. (2005). The relation of parenting styles and inconsistencies to adaptive functioning for children in conflictual and violent families. Journal of family violence, 20(5), 261277.

Slameto. (2010). Belajar dan Faktor-faktor yang Mempengaruhinya. Jakarta: Rineka Cipta. 